\title{
Complex roles of CAMP-PKA-CREB signaling in cancer
}

\author{
Hongying Zhang ${ }^{1}$, Qingbin Kong ${ }^{1}$, Jiao Wang ${ }^{2}$, Yangfu Jiang ${ }^{1}$ and Hui Hua ${ }^{3 *}$
}

\begin{abstract}
Cyclic adenosine monophosphate (CAMP) is the first discovered second messenger, which plays pivotal roles in cell signaling, and regulates many physiological and pathological processes. CAMP can regulate the transcription of various target genes, mainly through protein kinase A (PKA) and its downstream effectors such as CAMP-responsive element binding protein (CREB). In addition, PKA can phosphorylate many kinases such as Raf, GSK3 and FAK. Aberrant CAMP-PKA signaling is involved in various types of human tumors. Especially, CAMP signaling may have both tumor-suppressive and tumor-promoting roles depending on the tumor types and context. CAMP-PKA signaling can regulate cancer cell growth, migration, invasion and metabolism. This review highlights the important roles of CAMP-PKA-CREB signaling in tumorigenesis. The potential strategies to target this pathway for cancer therapy are also discussed.
\end{abstract}

Keywords: CAMP, PKA, CREB, Cancer

\section{Background}

Cell growth is tightly regulated by a variety of signal transduction pathways. Abnormal activation or inhibition of signal transduction pathways drives tumorigenesis. Posttranslational protein modifications, such as phosphorylation, ubiquitination, methylation and acetylation, are one of the important mechanisms that regulate cell signaling. Protein phosphorylation and dephosphorylation are regulated by various protein kinases and phosphatases, respectively. Abnormal or uncontrolled activation of protein kinases or phosphatases is very common in tumors, poising them as important targets for molecular targeted cancer therapeutics. As an inhibitor of the oncogenic kinase $\mathrm{BCR}-\mathrm{ABL}$, imatinib is the first kinase-targeted anticancer drug that has been successfully applied in the treatment of chronic myeloid leukemia [1]. Later on, inhibitors of protein kianses such as EGFR, ErbB2, MAPK, VEGFR and mTOR have been

\footnotetext{
*Correspondence: huahuihuaxi@163.com

${ }^{3}$ Laboratory of Stem Cell Biology, West China Hospital, Sichuan University, Chengdu 610041, China
}

Full list of author information is available at the end of the article widely used in the treatment of a variety of common malignant tumors [2-5].

Cell signaling is often initiated by first messengers such as growth factors, hormones and ions, which trigger a series of signal transduction cascades via membrane receptors or intracellular receptors. This process involves multiple feedback mechanisms as well as a number of intracellular chemicals, known as the second messengers, such as cyclic adenosine monophosphate (cAMP), cGMP, calcium ions and so on [6]. In general, the production and distribution of these second messengers also need precise regulation. Abnormal production and distribution of these second messengers may contribute to carcinogenesis and tumor progression. The second messenger theory was first proposed by E. W. Sutherland in 1965. As a second messenger, cAMP is responsible for activation of the protein kinase A (PKA), exchange proteins directly activated by cAMP (Epac) and ion gated channel protein [7]. As one of the target proteins of PKA, cAMP response element binding protein (CREB) is an important transcription factor that regulates the expression of several genes including oncogenes c-Jun and cyclin D1 [8]. Notably,

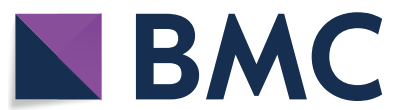

(c) The Author(s) 2020. This article is licensed under a Creative Commons Attribution 4.0 International License, which permits use, sharing, adaptation, distribution and reproduction in any medium or format, as long as you give appropriate credit to the original author(s) and the source, provide a link to the Creative Commons licence, and indicate if changes were made. The images or other third party material in this article are included in the article's Creative Commons licence, unless indicated otherwise in a credit line to the material. If material is not included in the article's Creative Commons licence and your intended use is not permitted by statutory regulation or exceeds the permitted use, you will need to obtain permission directly from the copyright holder. To view a copy of this licence, visit http://creativecommons.org/licenses/by/4.0/. The Creative Commons Public Domain Dedication waiver (http://creativecommons.org/publicdomain/zero/1.0/) applies to the data made available in this article, unless otherwise stated in a credit line to the data. 
cAMP-PKA-CREB signaling has both tumor-suppressive and tumot-promoting effects on cancer, depending on the tumor types and context.

\section{The generation and degradation of CAMP}

cAMP exists extensively in cells. Many hormones, neurotransmitters and other signaling molecules use it as intracellular second messenger. Therefore, cAMP can directly regulate various biological processes or behaviors of cells, including cell metabolism, ion channel activation, gene expression, cell growth, differention and apoptosis [9]. The generation of cAMP is regulated in a G-protein-dependent or G-protein-independent manner. After extracellular ligands, such as PGE2, GLP-1 and $\beta 2$ receptor agonists, bind to G-protein coupled receptors (GPCRs), G $\alpha$ subunits are separated from $G \beta$ and $G \gamma$ subunits, and then activate adenylyl cyclases (ACs), leading to the conversion of ATP into cAMP (Fig. 1) [10-12]. In addition, bicarbonate $\left(\mathrm{HCO}_{3}{ }^{-}\right)$and calcium ions $\left(\mathrm{Ca}^{2+}\right)$ induce cAMP synthesis by activating the soluble adenylyl cyclase (sAC) independent of G-proteins [13, 14]. In contrast, phosphodiesterases (PDEs) are responsible for the degradation of cAMP. So far, at least 22 PDEs have been identified [15]. The concentration of intracellular
cAMP depends on the relative balance between adenylyl cyclases and phosphodiesterases.

\section{The molecular targets and roles of CAMP in cancer cell growth, migration and metabolism}

As shown in Fig. 1, the major targets of cAMP include PKA, Epac1 and Epac2, and nucleotide-gated ion channels. The cAMP binding domain of Epac can bind a cAMP molecule, resulting in conformational changes of the protein thereby exposing the active site in catalytic domain. As a guanosine exchange factor (GEF), Epac can promote Ras family proteins Rap1 and Rap2 to release GDP and bind GTP, leading to the activation of Rap1/2 [16]. Epac regulates multiple cell processes mainly through Rap-GEF dependent and Rap-GEF independent pathways, including migration and focal adhesion formation, morphogenesis, cardiac output, neurotransmitter release, glucose homeostasis, exocytosis, cell proliferation, cell differentiation and cell survival [16]. cAMP can also bind to some nucleotide-gated ion channels and regulate their functions, such as cyclic nucleotide gated ion channels (CNG) and hyperpolarization-activated cyclic nucleotide-gated channel ( $\mathrm{HCN})$ [6]. These channels are non-selective cation channels that can conduct calcium, sodium and potassium ions and change the cell membrane potential. Below, we shall focus on PKA as a classical target of cAMP.

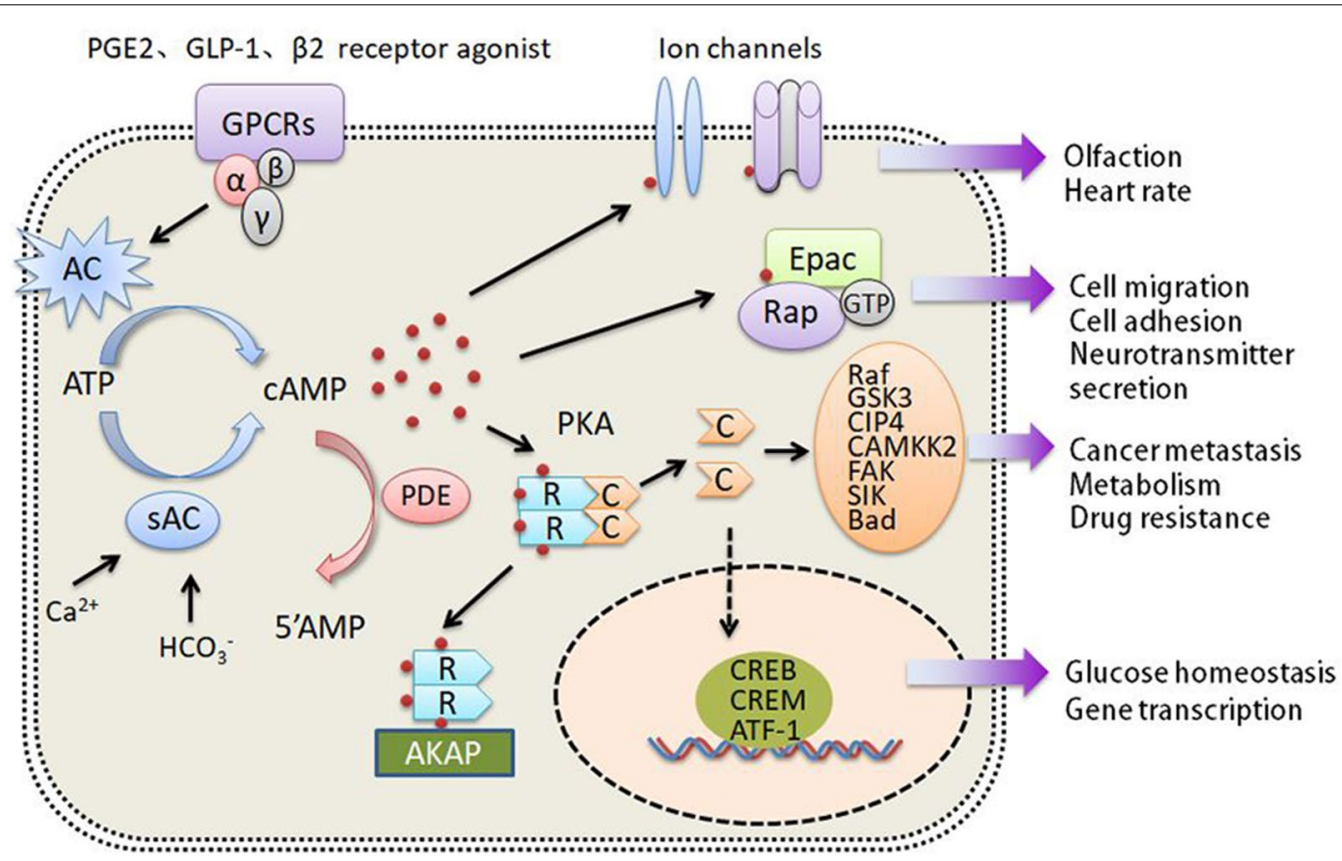

Fig. 1 CAMP signaling pathway. The generation of CAMP is regulated in a G-protein dependent manner by AC or G-protein independent manner by SAC. The degradation of CAMP is regulated by PDEs. CAMP can regulate multiple signaling pathways including ion channes, Epac, and PKA. $R$ the regulatory subunit of PKA, $C$ the catalytic subunit of PKA 
PKA is a tetramer enzyme consisting of two regulatory subunits (R) and two catalytic subunits (C) (Fig. 1). In mammals, there are four types of regulatory subunits, namely RI $\alpha$, RI $\beta$, RII $\alpha$ and RII $\beta$. According to the different regulatory subunits, PKA can be classified into PKA type I $\left(\mathrm{RI}_{2} \mathrm{C}_{2}, \mathrm{RI} \beta_{2} \mathrm{C}_{2}\right)$ and PKA type II $\left(\mathrm{RII}_{2} \mathrm{C}_{2}\right.$, $\mathrm{RII} \beta_{2} \mathrm{C}_{2}$ ) [17]. The binding to two regulatory subunits of the inactive PKA tetramer by cAMP results in the release and activation of the catalytic subunits, phosphorylation of the serine and threonine residues in substrate proteins [18]. RI $\alpha$ and RII $\alpha$ are widely distributed in different cells, while RI $\beta$ mainly exists in the brain, testis and B lymphocytes, and RII $\beta$ is expresses in the brain, fat, and some endocrine tissues [19]. The localization of the tetramer enzyme is also different. PKA type I are generally cytoplasmic, while PKA type II are specifically anchored in subcellular structures and compartments [20]. PKA anchored proteins (AKAPs) can bind to cytoskeleton proteins or organelles and to PKA regulatory subunits, thereby playing an important role in the distribution of PKA in cells and enabling PKA to park and concentrate key targets $[21,22]$. PKA type II is generally expressed in normal non-proliferating tissues and cells in growth retardation phase. PKA type I expression can be temporarily induced by physiological stimulation in cell proliferating phase and stimulated by certain growth factors and receptors, such as EGFR, TNF- $\alpha$, and ErbB-2. Moreover, PKA type $\mathrm{I}$ is overexpressed in a variety of primary tumors [23].

There are three types of PKA catalytic subunits, including $C \alpha, C \beta$ and $C \gamma$. $C \alpha$ and $C \beta$ are two major types and have multiple splice variants. This subtype diversity is an important mechanism for achieving the specificity of PKA signaling [24]. Once activated, PKA phosphorylates its substrates, such as CREB, Raf, Bad and GSK3 [25-27], and then regulates gene expression, cell survival and migration. Recent study indicates that PKA is an actomyosin contractility-regulated effector of cellular mechanotransduction and a regulator of mechanically guided cell migration [28]. PKA also phosphorylates CDC42 interacting protein 4 (CIP4), a coordinator of membrane deformation and actin polymerization, and promotes cancer cell invasion and metastasis [29]. Actually, the promotion of cancer cell invasion and metastasis by PKA may involve multiple PKA substrates. The focal adhesion kinase is another PKA target that mediates the promotion of cancer metastasis by cAMP [30].

In addition, PKA can phosphorylate and then inactivate the calmodulin-dependent protein kinase kinase-2 (CAMKK2) [31]. CaMKK2 plays important roles in energy homeostasis, insulin signaling and wholebody metabolism [32, 33]. Inhibition of CAMKK2 protects against prostate cancer, hepatocellular carcinoma
( $\mathrm{HCC})$ and metabolic disorders induced by a high-fat diet [34]. Moreover, PKA can reprogram lipid metabolism by inhibiting salt-inducible kinases, and then promote pancreatic tumorigenesis [35]. Meanwhile, PKA signaling cooperates with the epigenetic regulators JMJD3 and SIRT1 to activate $\beta$-oxidation-promoting genes [36]. There may be more and more metabolismrelated targets of PKA to be uncovered. Of note, activated PKA can feedback inhibit adenylyl cyclase (AC5 and AC6) and activate phosphodiesterase (PDE3 and PDE4) thereby lowering the levels of cAMP and maintaing cAMP homeostasis [12, 37].

The CREB family proteins are well-characterized PKA substrates. This family is a group of the basic leucine zipper (bZIP) superfamily transcription factors, including CREB, cAMP responsive element regulatory protein (CREM) and transcriptional activator 1 (ATF1). CREB, CREM and ATF1 can form homodimers or heterodimers [38-40]. Both CREB and ATF-1 proteins are ubiquitously expressed, while CREM is mostly expressed in neuroendocrine tissues [40]. The CREB family proteins contain a kinase inducible domain (KID), two glutamate domains (Q1 and Q2), and a basic leucine zipper domain (bZIP). KID is a 60-amino acid fragment located in the central region of CREB, CREM and ATF1, which contains the PKA phosphorylation site (RRPSY) (Fig. 2) [41].

Phosphorylation of CREB Ser ${ }^{133}$ residue and ATF1 $\mathrm{Ser}^{63}$ residue is critical for the transcriptional activity of CREB and ATF1. Activated ATF1 and CREB can form homodimer or heterodimer, bind to the cAMP response element (CRE) in the promoter region of target genes and initiate genes transcription, thereby regulating cell differentiation, proliferation, apoptosis, metabolism, glucose homeostasis, hematopoiesis, immune response as well as neuronal activities such as memory and learning (Fig. 3) [42-44]. In addition

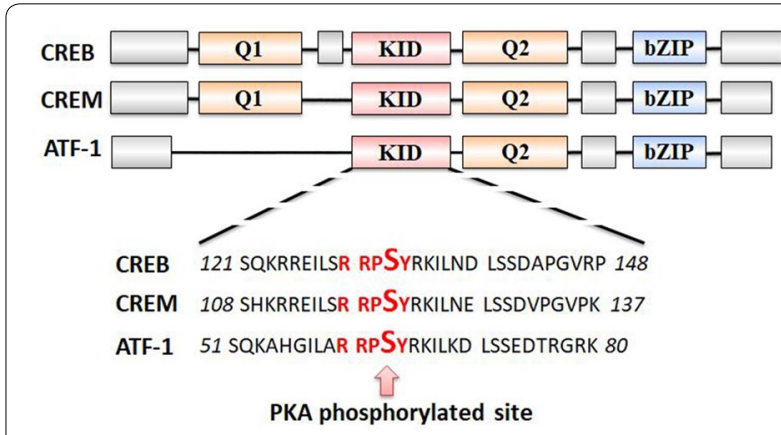

Fig. 2 The domains of CREB family proteins. The CREB family proteins contain a kinase inducible domain (KID), two glutamate domains (Q1 and Q2), and a basic leucine zipper domain (bZIP) 


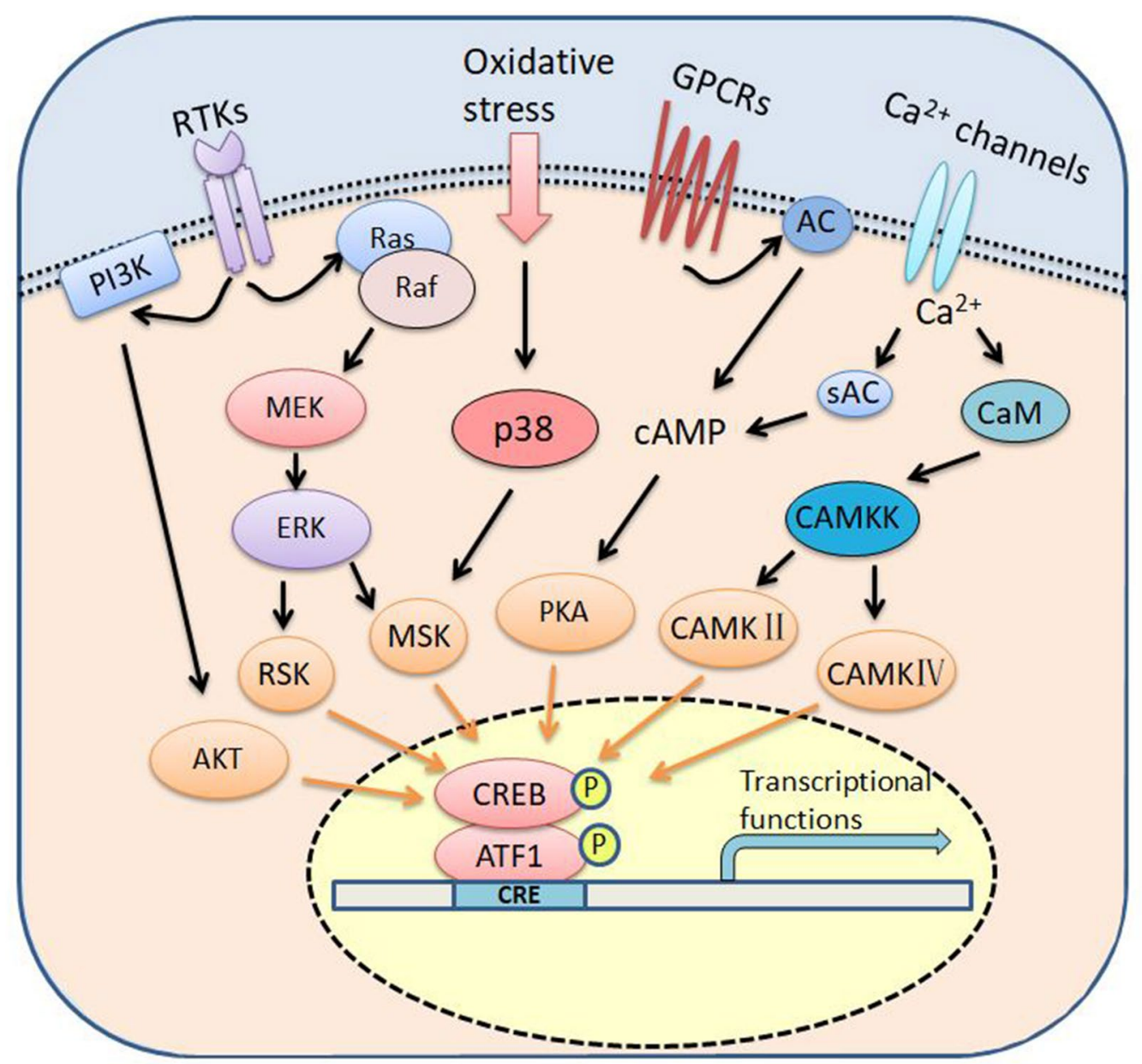

Fig. 3 Cell signaling pathways for activating CREB/ATF1. CREB/ATF1 can be phosphorylated by multiple kinases including Akt, RSK, MSK, PKA, CAMKII and CAMKIV

to the major PKA kinase, other kinases such as RSK, MSK, AKT, and CAMKII/IV also directly phosphorylate CREB and ATF1 [45-50].

\section{The roles of CAMP-PKA-CREB signaling pathway in tumors}

cAMP-PKA-CREB signaling has paradoxical effects in tumors, acts as a tumor-suppressor or tumor-promoter in different tumor types (Table 1). The role of cAMPPKA-CREB signaling pathway in liver cancer and other tumors is described below.

\section{Liver cancer}

Whereas some studies suggest that increasing cAMP levels may inhibit HCC cells growth [51-53], it has been reported that PKA promotes HCC invasion and metastasis by phosphorylating multiple substrates such as CIP4 [29]. Fibrolamellar hepatocellular carcinoma (FL-HCC) is a primary liver cancer that occurs mainly in children and young adults. $80 \%-100 \%$ FL-HCC patients have DNAJB1-PRKACA gene fusion, resulting in the deletion of a $400 \mathrm{~kb}$ gene fragment on chromosome 19 and the production of a chimeric protein that retains PKA kinase activity [54]. DNAJB1-PRKACA knock-in mice can develop tumors characteristics of FL-HCC [55]. In addition, PRKACA is overexpressed in about $80 \%$ of BAP1 gene (encoding BRCA1-associated protein 1)-mutated HCC, which exhibit similar clinical manifestations and histological characteristics to DNAJB1-PRKACA fusionrelated FL-HCC [56]. PKA pathway dysfunction plays an important role in the development and progression of these two kinds of HCC. Hepatitis B virus (HBV) infection is a major risk factor for the development of HCC. HBV X protein plays an important role in HBV-related HCC. Mechanistically, HBVx can promote liver carcinogenesis through CREB-miR-3188 and ZHX2-Notch signaling pathway [57], promote $\mathrm{HCC}$ cell growth by activating CREB-YAP axis [58], and promote the invasion 
Table 1 The diverse functions of CAMP/PKA/CREB in human tumors

\begin{tabular}{|c|c|c|}
\hline Cancer type & CAMP/PKA/CREB functions & References \\
\hline \multirow[t]{4}{*}{$\mathrm{HCC}$} & DNAJB1-PRKACA gene fusion in FL-HCC patients promote tumor progression & {$[54,55]$} \\
\hline & Overexpression of PRKACA in BAP1-mutated HCC promotes tumor progression & {$[56]$} \\
\hline & HBVx promotes liver carcinogenesis through CREB-miR-3188, CREB-YAP and Erk-CREB pathways & {$[57-59]$} \\
\hline & $\begin{array}{l}\text { CAMP analogues and PDE inhibitors inhibits HepG2 cell growth by down-regulating cyclin A and up- } \\
\text { regulating } \mathrm{p} 21 / \mathrm{p} 27 / \mathrm{p} 53\end{array}$ & {$[52,61]$} \\
\hline \multirow[t]{4}{*}{ Brain tumor } & cAMP inhibits glioblastoma cell growth by up-regulating p21/p27 and PKA/ Epac1-Rap1 signaling & {$[63-65]$} \\
\hline & PKA-Dock180 signaling promotes the development and invasion of glioblastoma & {$[74,75]$} \\
\hline & CAMP-PKA inhibits medulloblastoma by suppressing Hedgehog signaling & {$[66-68]$} \\
\hline & CREB promotes glioma progression through down-regulating PTEN & {$[72,76]$} \\
\hline \multirow[t]{3}{*}{ Lung cancer } & cAMP can down-regulate SIRT6 expression and inhibit NSCLC cells apoptosis & {$[78,79]$} \\
\hline & $\begin{array}{l}\text { PKA promotes hypoxia-induced epithelial-mesenchymal transformation, cell migration and invasion of } \\
\text { lung cancer cells }\end{array}$ & {$[84]$} \\
\hline & $\begin{array}{l}\text { PKA induces PP2A phosphorylation and AP1, thereby increases radiotherapy-induced lung cancer cell } \\
\text { apoptosis }\end{array}$ & {$[86,87]$} \\
\hline Prostate cancer & $\begin{array}{l}\text { PKA can up-regulate AR signaling and the neuroendocrine differentiation of prostate cancer, leading } \\
\text { to androgen-independence, resistance to androgen deprivation therapy and cancer progression }\end{array}$ & {$[81,88-93]$} \\
\hline Epithelial ovarian cancer & $\begin{array}{l}\text { PKA promotes extracellular matrix degradation and reduces the intensity of tight junction in epithelial } \\
\text { ovarian cancer cells by phosphorylating claudin-3, leading to tumor invasion and metastasis }\end{array}$ & {$[97-100]$} \\
\hline \multirow[t]{3}{*}{ Breast cancer } & $\begin{array}{l}\text { PKA promotes the growth and metastasis of triple negative breast cancer cells through GSK3- } \beta \text { - } \\
\text { catenin pathway }\end{array}$ & {$[104]$} \\
\hline & $\begin{array}{l}\text { PKA induces ERa Ser }{ }^{305} \text { phosphorylation, tamoxifen resistance and ER-positive breast cancer progres- } \\
\text { sion }\end{array}$ & {$[106,107]$} \\
\hline & PKA promotes trastuzumab resistance in Her-2 positive breast cancer & {$[108]$} \\
\hline \multirow[t]{3}{*}{ Leukemia and lymphoma } & CAMP promotes TLR signaling and apoptosis of chronic lymphocytic leukemia (CLL) cells & {$[112,113,119-121]$} \\
\hline & $\begin{array}{l}\text { CAMP_PKA may reduce Bcl-2 and survivin expression and increase Bax expression in lymphoma cells, } \\
\text { leading to cell apoptosis }\end{array}$ & {$[116-118]$} \\
\hline & $\begin{array}{l}\text { Overexpression of CREB in AML patients is associated with poor prognosis. Overexpression of CREB } \\
\text { can promote AML cells proliferation by up-regulating cyclin A1 expression }\end{array}$ & {$[122,123]$} \\
\hline
\end{tabular}

and metastasis of HBV-related HCC by up-regulating FOXM1 expression through Erk-CREB pathway [59]. Collectively, these studies indicate that the PKA-CREB pathway may promote HCC progression. Indeed, analysis of rat HCC tumors and paired normal liver samples showed significant increase in CREB and CREB phosphorylation levels in HCC [60].

However, the roles of cAMP in HCC appear to be somewhat paradoxical. As we described above, increasing cAMP levels by PDE inhibitors may arrest HCC cells growth. Treatment of HepG2 cells with cAMP analogues significantly reduce the transcription and protein levels of cyclin A and induce cell cycle arrest [61]. In addition, PDE4 inhibitor rolipram and DC-TA-46 can up-regulate the expression of p21, p27 and p53 and down-regulate cyclin A expression, thereby inhibiting the proliferation and promoting apoptosis of HepG2 cells [52]. In contrast, vasoactive intestinal peptide could reduce cAMP concentration, CREB expression and $\mathrm{Ser}^{133}$ phosphorylation, and inhibit Bcl-xL expression, leading to Huh7 cell apoptosis [62]. The versatile roles of cAMP in HCC may be due to the multiplicity of its targets with diverse functions. Hence, whether cAMP promotes or inhibits HCC may be context-dependent. The homeostasis in cAMP levels may be critical for HCC progression.

\section{Brain cancer}

The roles of the CREB-activating kinase PKA in brain tumors are also paradoxical. Several studies have shown that PKA plays a tumor-suppressive role in glioblastoma cell line A-172. Activation of PKA by increasing cAMP levels or supplying cAMP analogues (dcAMP and 8-BrcAMP) can reduce the proliferation rate of A-172 cells, promote differentiation, and induce apoptosis [63]. Increasing the intracellular cAMP levels by rolipram, a PDE inhibitor, can up-regulate the expression of p21 and p27, and activate PKA and Epac1-Rap1 signaling, leading to A-172 cell growth arrest and apoptosis [64,65]. cAMP pathway also plays anticancer role in medulloblastoma. Pituitary adenylyl cyclase inhibits the proliferation of medulloblastoma cells through PKA-Gli1 pathway [66], and neurociliary proteins inhibit the growth of medulloblastoma through PDE4D-PKA-Hedgehog pathway [67]. ARHGAP36 protein, a member of RhoGAP family, 
can bind to PKA catalytic subunit and inhibit its activity, thereby activating Hedgehog pathway and promoting the growth of medulloblastoma [68]. The tumor-suppressive effects of cAMP and PKA may be mediated by Epac1, Rap1 and Gli1, rather than CREB.

Phosphorylation of CREB can be directly inhibited by PTEN, an anticancer protein phosphatase that is frequently mutated or inactivated in many cancers, including the most aggressive types of brain cancer, glioblastoma multiforme and astrocytoma [69, 70]. PTEN deficiency can enhance CREB activity and induce the expression of PAX7, thereby promoting the conversion of human neural stem cells to glioblastoma stem-like cells [71]. In addition, CREB can reciprocally down-regulate PTEN. Tan et al. reported that CREB was highly expressed in clinical samples and cell lines of glioma, and CREB could inhibit PTEN expression through miR-23, thus promoting the development of glioma [72]. Moreover, EGFR can activate CREB through MAPK-RSK2 pathway, and then promote glioma cells growth and invasion [73].

Epidermal growth factor receptor (EGFR), EGFRvIII mutant and platelet derived growth factor receptor (PDGFR) can promote the development and invasion of glioblastoma through the PKA-Dock180 signaling pathway $[74,75]$. Also, miR-33a enhances cAMP-PKA signaling by inhibiting PDE8A expression, thus promoting the growth and self-renewal of initial glioma stem cells [76]. In human glioblastoma cell line MGR3, activation of PKA leads to a significant increase in GSTP1 phosphorylation and activity, which may lead to drug resistance and treatment failure [77].

\section{Lung cancer}

In non-small cell lung cancer (NSCLC), there are significant up-regulation of CREB expression and phosphorylation in tumor tissues compared with adjacent normal tissues. Increased CREB expression is correlated with short survival period of patients [78]. cAMP could down-regulate SIRT6 expression and thus reduce the apoptosis of NSCLC cells induced by radiotherapy [79]. In the highly malignancy small cell lung cancer (SCLC), increased activity of CREB helps maintain its neuroendocrine characteristics and proliferation [80]. RGS17 is increased in $80 \%$ of lung cancer tissues compared with matched normal lung tissue and promotes cell proliferation through the CAMP-PKA-CREB pathway [81]. In addition, PKA-Smurf1-PIPKIY signaling transduction promotes the progression of lung cancer in vivo [82]. cAMP-PKA-CREB pathway could regulate the hypoxia response in lung cancer cells [83]. PKA inhibitors H-89 and PKACA knockdown antagonize hypoxia-induced epithelial-mesenchymal transformation, cell migration, and invasion of lung cancer cells [84]. Moreover, oxidative stress plays an important role in the pathogenesis of lung diseases, including pulmonary fibrosis and lung cancer. Interactions among PKA, Erk $1 / 2$ and CREB mediate cell survival in oxidative stress [85].

Contradictory to the inhibition of radiotherapyinduced NSCLC cell apoptosis by cAMP-Sirt6 pathway [79], cAMP-PKA-CREB pathway seems to play an anticancer role in radiotherapy. BALB/c mice pretreatment with forskolin could inhibit ATM and NF-kB by PKAinduced PP2A phosphorylation, resulting in an increase in radiotherapy-induced apoptosis [86]. In lung cancer cell line H1299, Gs protein promotes Bak expression through PKA-CREB-AP1 pathway and increases apoptosis induced by radiotherapy [87]. These studies suggest that the CAMP-PKA-CREB pathway may also exert opposite effects under different circumstances of the same type of tumor.

\section{Prostate cancer}

PKA subunit can be a biomarker to predict the response of prostate cancer to radiotherapy and chemotherapy. Analysis of 456 clinical prostate cancer specimens found that PKA RI $\alpha$ is highly expressed in 80 cases $(17.5 \%)$, and PKA RI $\alpha$ overexpression is associated with poor efficacy of radiotherapy and short-term or long-term androgen deprivation therapy, distant metastasis and abnormal biochemical index [88]. In prostate cancer cell line PC3M cells, the overexpression of wild type PKA RII $\beta$ or mutant type PKA RI $\alpha-P$ (functionally similar with PKA RII $\beta$ ) leads to growth inhibition and apoptosis in vitro, and inhibits tumor growth in vivo [89]. Androgen receptor (AR) signaling is critical for prostate carcinogenesis. Testosterone directly stimulates GPR56 and then activates the cAMP/PKA pathway, which promotes AR signaling [90]. PKA also phosphorylates the $\mathrm{Thr}^{89}$ residue in HSP90, leading to the release of AR from HSP90 and the binding of AR to HSP27, which transfers AR into the nucleus to transactivate its targets [91]. In addition, PKA signaling pathway is involved in the neuroendocrine differentiation of prostate cancer, an early marker for the development of androgen independence [92, 93]. Moreover, high expressions of osteocalcin and ostesialin in androgen independent prostate cancer cell line $\mathrm{C} 4-2 \mathrm{~B}$ are dependent on the cAMP-PKA signaling pathway [94]. PAK4 can be activated by cAMP-PKA to enhance CREB transcription activity independent of phosphorylation at $\mathrm{Ser}^{133}$ residue, and PAK4 knockdown in PC-3 and DU145 cells inhibit tumor formation in nude mice [95]. Moreover, RGS17 is overexpressed in prostate cancer samples and promotes cell proliferation through the cAMP-PKA-CREB pathway [81]. In addition, it has been reported that depression and behavioral stress can 
accelerate the progression of prostate cancer through PKA kinase $[30,96]$.

\section{Ovarian cancer}

About $54 \%$ of epithelial-derived human ovarian tumors in tissue microarray have moderate or high levels of CREB expression, while no expression was observed in normal ovarian samples. Knockdown of CREB expression significantly reduces proliferation of ovarian cancer cells, but had no effect on apoptosis [97]. Epithelial ovarian cancer is one of the most deadly gynecologic malignant tumors. PKA RI $\alpha$ is highly expressed in epithelial ovarian cancer [98]. During metastatic spread of epithelial ovarian cancer cell line SKOV3, extracellular matrix invasion needs PKA activity and AKAPs anchor, and inhibition of PKA activity or PKA RI and RII anchor can block matrix invasion [99]. In addition, PKA reduces the intensity of tight junction in epithelial ovarian cancer cell line OVCA433 by phosphorylating claudin-3 [100]. Also, gonadotropin promotes the metastasis of epithelial ovarian cancer cells through PKA and PI3K pathways [101]. Whereas the above-mentioned studies suggest that PKACREB plays a tumor-promoting role in epithelial ovarian cancer, one study suggests that PKA can phosphorylate EZH2 at $\mathrm{Thr}^{372}$ residue, leading to mitochondrial dysfunction, the binding of EZH2 to STAT3 and then inhibiting STAT3 phosphorylation and epithelial ovarian cancer cell growth [102].

\section{Breast cancer}

Overexpression of R subunit especially RI of PKA is associated with cell proliferation in normal breast, malignant transformation of breast epithelial cells, poor prognosis of breast cancer, and tolerance to anti-estrogen therapy. Recent study demonstrates that nuclear localization of activated PKA is correlated with breast cancer metastasis [103]. Integrin $\alpha 9$ maintains the stability of $\beta$-catenin through ILK/PKA/GSK3 signaling and, thereby promotes the growth and metastasis of triple negative breast cancer cells [104]. Moreover, successful anti-estrogen therapy is associated with reduced RI mRNA expression, and RI antisense oligonucleotides can reduce the growth rate of breast cancer cells [105]. In estrogen receptor positive breast cancer, PKA-induced ER $\alpha \operatorname{Ser}^{305}$ phosphorylation and PAK1 are associated with tamoxifen resistance and breast cancer progression [106, 107]. In Her-2 positive breast cancer cells, PKA activation is associated with trastuzumab resistance [108]. In addition, cAMP-PKACREB pathway also plays an important role in the metabolic regulation of breast cancer. Serotonin promotes mitochondrial biosynthesis through the AC-PKA pathway in breast cancer cells [109]. Cytoplasmic G-protein coupled estrogen receptor promotes aerobic glycolysis through cAMP-PKA-CREB pathway [110]. Contrary to above studies, it is reported that IL-24 induces breast cancer cells apoptosis by activating TP53 and endoplasmic reticulum stress through PKA [111]. Hence, PKA may also have paradoxical roles in breast cancer depending on the context.

\section{Leukemia}

The role of cAMP is quite different in diverse types of lymphoma. PDE4 inhibitors block intracellular TLR signaling and promote apoptosis of chronic lymphocytic leukemia (CLL) cells through increasing cAMP concentration $[112,113]$. Interestingly, PDE4 inhibitors induce apoptosis in B cell CLL but not in T cell CLL or normal circulating hematopoietic cells, probably due to that PDE4 inhibitors only augment glucocorticoid receptor and cAMP levels in B cell CLL $[114,115]$. cAMP-PKA could promote apoptosis through mitochondria dependent pathways, reducing expression of anti-apoptotic proteins Bcl-2 and survivin, and increasing expression of pro-apoptotic protein Bax in lymphoma cells [116-118]. The chemokines CXCR4 and CXCL12 released from the microenvironment can bind to Gai-conjugated GPCRs on CLL cells, reducing cAMP synthesis and increasing survival rate of CLL cells $[119,120]$. PDE7B is overexpressed in CLL, and inhibitors of PDE7 (BRL-50481 and IR-202) and a dual PDE4/PDE7 inhibitor IR-284 increase apoptosis of CLL cells, which is attenuated by PKA inhibition [121].

CREB is overexpressed in the bone marrow of most leukemia cell lines and patients with acute myeloid leukemia (AML) and acute lymphoblastic leukemia (ALL) [122]. Previous studies also show that CREB is highly expressed in the majority of myeloid leukemia cells in AML patients and associated with poor prognosis [123]. The jmjd3/UTX inhibitor GSKJ4 can promote CREB degradation and inhibit AML cell growth [123]. Overexpression of CREB can promote AML cells proliferation by up-regulating cyclin $\mathrm{A} 1$ expression. In addition, the CREB transgenic mice shows myeloproliferative diseases but not leukemia, suggesting that CREB is involved in the leukemia phenotype during the leukemia germination, but is not sufficient to completely transform into leukemia [124]. In contrast, cAMP can protect acute promyelocytic leukemia cells from apoptosis induced by arsenic trioxide and anthracyclines [124]. In AML cell line IPC81, cAMP can induce apoptosis through up-regulation of Bim by CREB and CDK [125].

\section{Other tumors}

The mRNA and protein levels of PKA RI $\alpha$ and AKAP10 are significantly increased in colorectal cancer tissues, correlating with invasion depth, differentiation degree 
and short survival [126]. Type-I insulin-like growth factor receptor (IGF-IR) is tightly involved in tumorigenesis and drug resistance [127]. IGF-IR signaling induces ezrin phosphorylation at $\mathrm{Thr}^{567}$ residue and thereby promotes cAMP-dependent PKA activation and colorectal cancer cell survival [128]. Overexpression of PKA RI $\alpha$ and AKAP10 in several colorectal cancer cell lines is directly correlated to metastasis. In addition, the resistance of colorectal cancer cells to a selective MEK1/2 inhibitor selumetinib is induced by PKA activation [129], and the resistance of colorectal cancer cells to methotrexate can be induced by cAMP signaling [130]. PKA antagonists could inhibit the nuclear translocation of $\beta$-catenin and expression of c-myc and COX2 in APC mutant colorectal cancer, thereby inhibiting tumor development [131].

Immunohistochemical experiments found that normal melanocytes did not express PKA RI $\alpha$ proteins, but it is highly expressed in human melanoma samples and some melanoma cell lines. RII activation or RI $\alpha$ silence can inhibit proliferation and increase caspase 3-promoted apoptosis [132]. PKA can promote the migration of melanoma cells. Studies have found that hypoxia can induce the expression of scaffold protein AKAP12 in melanoma, and PKA-regulated phosphorylation during hypoxia is dependent on the presence of AKAP12. Inactivation of AKAP12 leading to the reduction of tumor growth, migration, and invasion in melanoma mouse models [133]. PKA pathway also plays an important role in the synthesis of melanin. Diethylstilbestrol can promote melanin production through CAMP-PKA mediated up-regulation of tyrosinase and MITF in mouse melanoma cell line B16 [134], and gingerol inhibits melanin production by down-regulating MAPK and PKA [135].

\section{Targeting CAMP-PKA pathway for cancer therapy}

Given the involvement of cAMP-PKA pathway in tumor progression, targeting this pathway may be a potential strategy to treat cancer. The cAMP analogue 8-Cl-cAMP, also known as tacladesine, can inhibit the growth of colon cancer, breast cancer, lung cancer, fibrosarcoma and leukemia in vitro and in vivo $[136,137]$. Due to the different binding affinity with PKA $\mathrm{R}$ subunits, 8-Cl-cAMP can down-regulate RI $\alpha$ and induce RII $\beta$ expression [136]. Some researchers have proposed that 8 -Cl-cAMP may also exert PKA-independent anti-tumor effects through its metabolite 8-Cl-adenosine and AKT2-PKB $\beta$ pathway [138, 139]. Although its anti-tumor mechanisms have not been fully elucidated, 8-Cl-cAMP has been tested in phase II clinical trials in patients with multiple myeloma and in phase I clinical trials in patients with metastatic colorectal cancer, but the results of these trials have not been disclosed (Table 2).

Since cAMP has tumor suppressive roles in some types of cancer, increasing cAMP levels may inhibit these types of tumors. PDE inhibitors can suppress the depletion of cAMP. Notably, PDE inhibitors have been widely used in clinic to treat cardiovascular, respiratory and psychiatic diseases. The PDE3 inhibitors amrinone and milrinone are used as cardiotonic drugs. PDE4 inhibitor rolipram is a new anti-inflammatory drug for asthma treatment. PDE5 inhibitor sildenafil is a preferred drug for erectile dysfunction treatment [140]. In addition, some flavonoids natural products can also inhibit PDEs [141]. These PDE inhibitors may be repurposed to treat cancers in which cAMP has tumor-suppressive roles. In contrast, PDE activators may be developed to treat cancers that are promoted by cAMP signaling. Recently, a small-molecule compound that allosterically activates PDE4 long isoforms has been developed [142]. This prototypical PDE4 activator compound is able to reduce intracellular cAMP levels and inhibit cyst formation in the kidney [142]. It remains to know whether such kinds of PDE activators may be repurposed to treat some types of cancer.

Antisense oligonucleotide targeting the $\mathrm{N}$-terminal PKA RI $\alpha$ is another choice to interfere with PKA signaling. PKA RI $\alpha$ knockdown leads to compensative expression of RII $\beta$ and then inhibits tumor growth in a wide variety of tumor models [143]. The antisense

Table 2 Clinical study of antitumor drugs targeting cAMP-PKA pathway (from clinicaltrials.gov)

\begin{tabular}{|c|c|c|c|}
\hline Identifier & Title & Cancer type & Locations \\
\hline NCT00004902 & $\begin{array}{l}\text { Tocladesine in treating patients with recur- } \\
\text { rent or refractory multiple myeloma }\end{array}$ & Multiple myeloma and plasma cell tumor & $\begin{array}{l}\text { Robert H. Lurie Comprehensive Cancer } \\
\text { Center, Northwestern University } \\
\text { Chicago, Illinois, United States }\end{array}$ \\
\hline NCT00021268 & $\begin{array}{l}\text { Tocladesine in treating patients with recur- } \\
\text { rent or progressive metastatic colorectal } \\
\text { cancer }\end{array}$ & Colorectal cancer & $\begin{array}{l}\text { Jonsson Comprehensive Cancer Center, UCLA } \\
\text { Los Angeles, California, United States }\end{array}$ \\
\hline NCT00004864 & $\begin{array}{c}\text { Docetaxel and GEM } 231 \text { in treating patients } \\
\text { with recurrent or refractory solid tumors }\end{array}$ & Unspecified adult solid tumor & $\begin{array}{l}\text { Albert Einstein Comprehensive Cancer Center } \\
\text { Bronx, New York, United States }\end{array}$ \\
\hline NCT00004863 & $\begin{array}{l}\text { Paclitaxel and GEM } 231 \text { in treating patients } \\
\text { with recurrent or refractory solid tumors }\end{array}$ & Unspecified adult solid tumor & $\begin{array}{l}\text { Albert Einstein Comprehensive Cancer Center } \\
\text { Bronx, New York, United States }\end{array}$ \\
\hline
\end{tabular}


oligonucleotide GEM231 has been evaluated in two phase I clinical trials (Table 2). The results of the phase I clinical trial of GEM231 in combination with docetaxel showed that the overall incidence of grade 3 adverse reactions, including fatigue, elevated aminotransferase, neutropenia and altered mental status, was $75 \%$ in 20 patients with refractory solid tumors during 39 cycles of treatment [144]. No subsequent clinical trial has been reported.

CREB may also be a target for cancer therapy. Currently, there is no specific CREB inhibitor. The small molecule XX-650-23 blocks the interaction between CREB and its co-activator CBP (CREB-binding protein) and then abrogates CREB-responsive gene expression, leading to AML cells apoptosis and cell-cycle arrest [145, 146]. Another feasible strategy is to downregulate CREB expression. Previous study demonstrates that GSKJ4, the histone lysine demethylases JMJD3/UTX inhibitor, can induce CREB degradation and inhibit AML cell growth [123]. Given that JMJD3/UTX have multiple targets, GSKJ4 may also inhibit cancer cell growth by targeting proteins other than CREB. Since CREB may be activated by CAMK in some types of cancer, inhibition of CAMK may be an alternative strategy to suppress CREB [147].

Although there are some PKA inhibitors that have tumor-suppressive effects in preclinical studies, no smallmoleculae PKA inhibitors have been tested in clinical trials. It warrants further research to develop more smallmolecule drugs targeting PKA and/or CREB, and evaluate their safety and efficacy in cancer therapy. In addition, repurposing some drugs that can act on PKA and CREB may be valuable to cancer therapy.

\section{Concluding remarks}

cAMP signaling pathway is evolutionarily conserved and plays key roles in major physiological and pathological processes. The functions of cAMP signaling in tumors depend on cell type and specific environment. In many types of human tumors, cAMP-PKA-CREB pathway plays a tumor-promoting role. The abnormal activation of this pathway and its interaction with other signaling pathways are closely related to tumorigenesis, invasion, metastasis and drug resistance. In contrast, cAMP and CREB also have tumor-suppressive roles in some types of tumors, such as medulloblastoma and non-Hodgkin's lymphoma [148-150]. While cAMP may inhibit tumor progression through downregulating cyclin A, Erk or other targets, PKA also reportedly inhibits some tumorpromoting signals. For example, PKA may inhibit the activity of mTORC1, an important tumor-promoter, through phosphorylating the mTORC1 component Raptor on $\mathrm{Ser}^{791}$ residue $[4,151]$. It warrants further studies to determine whether targeting cAMP-PKA-CREB pathway is a feasible strategy to treat cancer and reverse cancer drug resistance.

\section{Abbreviations}

ACs: Adenylyl cyclases; AKAPs: Protein kinase A anchoring proteins; ALL: Acute lymphocytic leukemia; AML: : Acute myeloid leukemia; AR: Androgen receptor; ATF1: Activating transcription factor 1; CAMKK2: Calmodulin-dependent protein kinase kinase-2; CAMP: Cyclic adenosine monophosphate; CBP: CREBbinding protein; CIP4: CDC42 interacting protein 4; CLL: Chronic lymphocytic leukemia; CNG: Cyclic nucleotide gated ion channels; CRE: CAMP response element; CREB: CAMP response element binding protein; CREM: CRE modulator; EGFR: Epidermal growth factor receptor; Epac1/2: Exchange proteins directly activated by CAMP 1 and 2; FL-HCC: Fibrolamellar hepatocellular carcinoma; GBM: Glioblastoma; GEFs: Guanine nucleotide exchange factor; GLP-1:

Glucagon-like peptide 1; GPCRs: G-protein-coupled receptors; HBV: Hepatitis B virus; HCC: Hepatocellular carcinoma; HCN: Hyperpolarization-activated cyclic nucleotide-gated channel; IGF-1R: Type-I insulin-like growth factor receptor; KID: Kinase inducible domain; NSCLC: Non-small cell lung cancer; PDEs: Phosphodiesterases; PDGFR: Platelet derived growth factor receptor; PGE2: Prostaglandin E2; PKA: CAMP-activated protein kinases; SAC: Soluble adenylyl cyclase; SCLC: Small cell lung cancer; VEGFR: Vascular endothelial growth factor receptor.

\section{Acknowledgements}

We would like to thank Qiulin Tang for her assistance in preparing the manuscript.

\section{Authors' contributions}

$\mathrm{HH}, \mathrm{HZ}$ and $\mathrm{YJ}$ conceived the review and wrote the manuscript. $\mathrm{HZ}$ and $\mathrm{QK}$ prepared the figures. JW edited the references.

\section{Funding}

This work was supported by Grant 81872388 from the National Natural Science Foundation of China and Grant 2018SCUH0009 from the Fundamental Research Fund for the Central Universities.

\section{Availability of data and materials}

Not applicable.

Ethics approval and consent to participate

Not applicable.

Consent for publication

Not applicable.

\section{Competing interests}

The authors declare that they have no competing interests.

\section{Author details}

${ }^{1}$ Laboratory of Oncogene, National Clinical Research Center for Geriatrics, West China Hospital, Sichuan University, Chengdu, China. ${ }^{2}$ School of Basic Medicine, Chengdu University of Traditional Chinese Medicine, Chengdu, China. ${ }^{3}$ Laboratory of Stem Cell Biology, West China Hospital, Sichuan University, Chengdu 610041, China.

Received: 11 November 2020 Accepted: 19 November 2020 Published online: 24 November 2020

\footnotetext{
References

1. Braun TP, Eide CA, Druker BJ. Response and resistance to BCR-ABL1targeted therapies. Cancer Cell. 2020;37:530-42.

2. Lim ZF, Ma PC. Emerging insights of tumor heterogeneity and drug resistance mechanisms in lung cancer targeted therapy. J Hematol Oncol. 2019;12:134
} 
3. Qin S, Li A, Yi M, Yu S, Zhang M, Wu K. Recent advances on antiangiogenesis receptor tyrosine kinase inhibitors incancer therapy. J Hematol Oncol. 2019;12:27.

4. Lee YT, Tan YJ, Oon CE. Molecular targeted therapy: treating cancer with specificity. Eur J Pharmacol. 2018;834:188-96.

5. Hua H, Kong Q, Zhang H, Wang J, Luo T, Jiang Y. Targeting mTOR for cancer therapy. J Hematol Oncol. 2019;12:71.

6. Fajardo A, Piazza G, Tinsley H. The role of cyclic nucleotide signaling pathways in cancer: targets for prevention and treatment. Cancers. 2014;6:436-58.

7. Sassone-Corsi P. The cyclic AMP pathway. Cold Spring Harb Perspect Biol. 2012:4:a011148.

8. Steven A, Friedrich M, Jank P, Heimer N, Budczies J, Denkert C, et al. What turns CREB on? And off? And why does it matter? Cell Mol Life Sci. 2020;77:4049-67.

9. Chin KV, Yang WL, Ravatn R, Kita T, Reitman E, Vettori D, et al. Reinventing the wheel of cyclic AMP: novel mechanisms of CAMP signaling. Ann NY Acad Sci. 2002;968:49-64.

10. Kimple ME, Keller MP, Rabaglia MR, Pasker RL, Neuman JC, Truchan $N A$, et al. Prostaglandin E2 receptor, EP3, is induced in diabetic islets and negatively regulates glucose- and hormone-stimulated insulin secretion. Diabetes. 2013;62:1904-12.

11. Ali DC, Naveed M, Gordon A, Majeed F, Saeed M, Ogbuke MI, et al. $\beta$-Adrenergic receptor, an essential target in cardiovascular diseases. Heart Fail Rev. 2020;25:343-54.

12. Khannpnavar B, Mehta V, Qi C, Korkhov V. Structure and function of adenylyl cyclases, key enzymes in cellular signaling. Curr Opin Struct Biol. 2020;63:34-41.

13. Kleinboelting S, Diaz A, Moniot S, van den Heuvel J, Weyand M, Levin $L R$, et al. Crystal structures of human soluble adenylyl cyclase reveal mechanisms of catalysis and of its activation through bicarbonate. Proc Natl Acad Sci USA. 2014;111:3727-32.

14. Litvin TN, Kamenetsky M, Zarifyan A, Buck J, Levin LR. Kinetic properties of "soluble" adenylyl cyclase. Synergism between calcium and bicarbonate. J Biol Chem. 2003:278:15922-6.

15. Omori K, Kotera J. Overview of PDEs and their regulation. Circ Res. 2007;100:309-27.

16. Formoso K, Lezoualc'h F, Mialet-Perez J. Role of EPAC1 signalosomes in cell fate: friends or foes? Cells. 2020;9:E1954.

17. Taskén K, Skålhegg BS, Solberg R, Andersson KB, Taylor SS, Lea T, et al. Novel isozymes of CAMP-dependent protein kinase exist in human cells due to formation of RI alpha-Rl beta heterodimeric complexes. J Biol Chem. 1993;268:21276-83.

18. Taskén K, Skålhegg BS, Taskén KA, Solberg R, Knutsen HK, Levy FO, et al. Structure, function, and regulation of human CAMP-dependent protein kinases. Adv Second Messenger Phosphoprotein Res. 1997;31:191-204.

19. Skålhegg B, Taskén K. Specificity in the CAMP/PKA signaling pathway. Differential expression, regulation, and subcellular localization of subunits of PKA. Front Biosci. 2000;5:D678-93.

20. Gold MG, Lygren B, Dokurno P, Hoshi N, Mcconnachie G, Taskén K, et al. Molecular basis of AKAP specificity for PKA regulatory subunits. Mol Cell. 2006;24:383-95.

21. Smith FD, Langeberg LK, Scott JD. The where's and when's of kinase anchoring. Trends Biochem Sci. 2006;31:316-23.

22. Bucko PJ, Scott JD. Drugs that regulate local cell signaling: AKAP targeting as a therapeutic option. Annu Rev Pharmacol Toxicol. 2020. https://doi.org/10.1146/annurev-pharmtox-022420-112134.

23. Melisi D, Troiani T, Damiano V, Tortora G, Ciardiello F. Therapeutic integration of signal transduction targeting agents and conventional anti-cancer treatments. Endocr Relat Cancer. 2004;11:51-68.

24. Wu J, Brown SHJ, Von Daake S, Taylor SS. PKA type lla holoenzyme reveals a combinatorial strategy for isoform diversity. Science. 2007:318:274-9.

25. Häfner S, Adler HS, Mischak H, Janosch P, Heidecker G, Wolfman A, et al. Mechanism of inhibition of Raf-1 by protein kinase A. Mol Cell Biol. 1994;14:6696-703.

26. Zhao L, Liu J, He C, Yan R, Zhou K, Cui Q, et al. Protein kinase A determines platelet life span and survival by regulating apoptosis. J Clin Invest. 2017;127:4338-51.
27. Jensen J, Brennesvik EO, Lai YC, Shepherd PR. GSK-3beta regulation in skeletal muscles by adrenaline and insulin: evidence that PKA and PKB regulate different pools of GSK-3. Cell Signal. 2007;19:204-10.

28. McKenzie AJ, Svec KV, Williams TF, Howe AK. Protein kinase A activity is regulated by actomyosin contractility during cell migration and is required for durotaxis. Mol Biol Cell. 2020;31:45-58.

29. Tonucci FM, Almada E, Borini-Etichetti C, Pariani A, Hidalgo F, Rico MJ, et al. Identification of a CIP4 PKA phosphorylation site involved in the regulation of cancer cell invasiveness and metastasis. Cancer Lett. 2019;461:65-77.

30. Cheng Y, Gao XH, Li XJ, Cao QH, Zhao DD, Zhou JR, et al. Depression promotes prostate cancer invasion and metastasis via a sympatheticCAMP-FAK signaling pathway. Oncogene. 2018;37:2953-66.

31. Langendorf CG, O'Brien MT, Ngoei KRW, McAloon LM, Dhagat U, Hoque $A$, et al. CaMKK2 is inactivated by CAMP-PKA signaling and 14-3-3 adaptor proteins. J Biol Chem. 2020. https://doi.org/10.1074/jbc.RA120 .013756.

32. Marcelo KL, Ribar T, Means CR, Tsimelzon A, Stevens RD, Ilkayeva O, et al. Research resource: roles for calcium/calmodulin-dependent protein kinase kinase 2 (CaMKK2) in systems metabolism. Mol Endocrinol. 2016;30:557-72.

33. Marcelo KL, Means AR, York B. The $\mathrm{Ca}(2+) /$ calmodulin/CaMKK2 axis: nature's metabolic CaMshaft. Trends Endocrinol Metab. 2016;27:706-18.

34. Lin F, Marcelo KL, Rajapakshe K, Coarfa C, Dean A, Wilganowski N, et al. The camKK2/camKIV relay is an essential regulator of hepatic cancer. Hepatology. 2015;62:505-20.

35. Patra KC, Kato Y, Mizukami Y, Widholz S, Boukhali M, Revenco I, et al. Mutant GNAS drives pancreatic tumourigenesis by inducing PKAmediated SIK suppression and reprogramming lipid metabolism. Nat Cell Biol. 2018;20:811-22.

36. Seok S, Kim YC, Byun S, Choi S, Xiao Z, Iwamori N, et al. Fasting-induced JMJD3 histone demethylase epigenetically activates mitochondrial fatty acid $\beta$-oxidation. J Clin Invest. 2018;128:3144-59.

37. Murthy KS, Zhou H, Makhlouf GM. PKA-dependent activation of PDE3A and PDE4 and inhibition of adenylyl cyclase V/NI in smooth muscle. Am J Physiol Cell Physiol. 2002;282:C508-17.

38. Montminy MR, Bilezikjian LM. Binding of a nuclear protein to the cyclic-AMP response element of the somatostatin gene. Nature. 1987;328:175-8.

39. Hai TW, Liu F, Allegretto EA, Karin M, Green MR. A family of immunologically related transcription factors that includes multiple forms of ATF and AP-1. Genes Dev. 1988:2:1216-26.

40. Foulkes NS, Borrelli E, Sassone-Corsi P. CREM gene: use of alternative DNA-binding domains generates multiple antagonists of CAMPinduced transcription. Cell. 1991;64:739-49.

41. Sandoval S, Pigazzi M, Sakamoto KM. CREB: a key regulator of normal and neoplastic hematopoiesis. Adv Hematol. 2009:634292.

42. Rehfuss RP, Walton KM, Loriaux MM, Goodman RH. The cAMP-regulated enhancer-binding protein ATF-1 activates transcription in response to CAMP-dependent protein kinase A. J Biol Chem. 1991;266:18431-4.

43. Siu YT, Jin DY. CREB-a real culprit in oncogenesis. FEBS J. 2007;274:3224-32.

44. Xiao X, Li BX, Mitton B, Ikeda A, Sakamoto KM. Targeting CREB for cancer therapy: friend or foe. Curr Cancer Drug Targets. 2010;10:384-91.

45. Johannessen M, Moens U. Multisite phosphorylation of the CAMP response element-binding protein (CREB) by a diversity of protein kinases. Front Biosci. 2007;12:1814-32.

46. Liu K, Cho YY, Yao K, Nadas J, Kim DJ, Cho EJ, et al. Eriodictyol inhibits RSK2-ATF1 signaling and suppresses EGF-induced neoplastic cell transformation. J Biol Chem. 2011;286:2057-66.

47. Wiggin GR, Soloaga A, Foster JM, Murray-Tait V, Cohen P, Arthur JS. MSK1 and MSK2 are required for the mitogen- and stress-induced phosphorylation of CREB and ATF1 in fibroblasts. Mol Cell Biol. 2002;22:2871-81.

48. Rastogi R, Jiang Z, Ahmad N, Rosati R, Liu Y, Beuret L, et al. Rapamycin induces mitogen-activated protein (MAP) kinase phosphatase-1 (MKP1) expression through activation of protein kinase $B$ and mitogen-activated protein kinase kinase pathways. J Biol Chem. 2013;288:33966-77.

49. Shimomura A, Ogawa Y, Kitani T, Fujisawa H, Hagiwara M. Calmodulindependent protein kinase II potentiates transcriptional activation through activating transcription factor 1 but not CAMP response element-binding protein. J Biol Chem. 1996;271:17957-60. 
50. Feliciano DM, Edelman AM. Repression of $\mathrm{Ca}^{2+} /$ calmodulin-dependent protein kinase IV signaling accelerates retinoic acid-induced differentiation of human neuroblastoma cells. J Biol Chem. 2009;284:26466-81.

51. Massimi M, Ragusa F, Cardarelli S, Giorgi M. Targeting cyclic AMP signalling in hepatocellular carcinoma. Cells. 2019;8:1511.

52. Massimi M, Cardarelli S, Galli F, Giardi MF, Ragusa F, Panera N, et al. Increase of intracellular cyclic AMP by PDE4 inhibitors affects HepG2 cell cycle progression and survival. J Cell Biochem. 2017;1 18:1401-11.

53. Peng T, Gong J, Jin Y, Zhou Y, Tong R, Wei X, et al. Inhibitors of phosphodiesterase as cancer therapeutics. Eur J Med Chem. 2018;150:742-56.

54. Graham RP, Jin L, Knutson DL, Kloft-Nelson SM, Greipp PT, Waldburger $\mathrm{N}$, et al. DNAJB1-PRKACA is specific for fibrolamellar carcinoma. Mod Pathol. 2015:28:822-9.

55. Engelholm LH, Riaz A, Serra D, Dagnæs-Hansen F, Johansen JV, SantoniRugiu E, et al. CRISPR/Cas9 engineering of adult mouse liver demonstrates that the Dnajb1-Prkaca gene fusion is sufficient to induce tumors resembling fibrolamellar hepatocellular carcinoma. Gastroenterology. 2017;153:1662-73.

56. Hirsch TZ, Negulescu A, Gupta B, Caruso S, Noblet B, Couchy G, et al. BAP1 mutations define a homogeneous subgroup of hepatocellular carcinoma with fibrolamellar-like features and activated PKA. J Hepatol. 2020;72:924-36

57. Zhou SJ, Deng YL, Liang HF, Jaoude JC, Liu FY. Hepatitis B virus X protein promotes CREB-mediated activation of miR-3188 and Notch signaling in hepatocellular carcinoma. Cell Death Differ. 2017;24:1577-87.

58. Zhang T, Zhang J, You X, Liu Q, Du Y, Gao Y, et al. Hepatitis B virus X protein modulates oncogene Yes-associated protein by CREB to promote growth of hepatoma cells. Hepatology. 2012;56:2051-9.

59. Xia L, Huang W, Tian D, Zhu H, Zhang Y, Hu H, et al. Upregulated FoxM1 expression induced by hepatitis $B$ virus $X$ protein promotes tumor metastasis and indicates poor prognosis in hepatitis $B$ virus-related hepatocellular carcinoma. J Hepatol. 2012;57:600-12.

60. Kovach SJ, Price JA, Shaw CM, Theodorakis NG, Mckillop IH. Role of cyclic-AMP responsive element binding (CREB) proteins in cell proliferation in a rat model of hepatocellular carcinoma. J Cell Physiol. 2006;206:411-9.

61. Lee J, Choi YH, Nguyen P, Kim J-S, Lee SJ, Trepel JB. Cyclic AMP induces inhibition of cyclin A expression and growth arrest in human hepatoma cells. Biochim Biophys Acta. 1999;1449:261-8.

62. Hara M, Takeba Y, liri T, Ohta Y, Ootaki M, Watanabe M, et al. Vasoactive intestinal peptide increases apoptosis of hepatocellular carcinoma by inhibiting the CAMP/BCl-xL pathway. Cancer Sci. 2019;110:235-44.

63. Chen TC, Hinton DR, Zidovetzki R, Hofman FM. Up-regulation of the CAMP/PKA pathway inhibits proliferation, induces differentiation, and leads to apoptosis in malignant gliomas. Lab Invest. 1998;78:165-74.

64. Chen TC, Wadsten P, Su S, Rawlinson N, Hofman FM, Hill CK, et al. The type IV phosphodiesterase inhibitor rolipram induces expression of the cell cycle inhibitors p21(Cip1) and p27(Kip1), resulting in growth inhibition, increased differentiation, and subsequent apoptosis of malignant A-172 glioma cells. Cancer Biol Ther. 2002;1:268-76.

65. Moon EY, Lee GH, Lee MS, Kim HM, Lee JW. Phosphodiesterase inhibitors control A172 human glioblastoma cell death through CAMP-mediated activation of protein kinase A and Epac1/Rap1 pathways. Life Sci. 2012;90:373-80.

66. Cohen JR, Resnick DZ, Niewiadomski P, Dong H, Liau LM, Waschek JA. Pituitary adenylyl cyclase activating polypeptide inhibits gli1 gene expression and proliferation in primary medulloblastoma derived tumorsphere cultures. BMC Cancer. 2010;10:676.

67. Ge X, Milenkovic L, Suyama K, Hartl T, Purzner T, Winans A, et al. Phosphodiesterase 4D acts downstream of Neuropilin to control Hedgehog signal transduction and the growth of medulloblastoma. Elife. 2015:4:e07068.

68. Eccles RL, Czajkowski MT, Barth C, Müller PM, Mcshane E, Grunwald S, et al. Bimodal antagonism of PKA signalling by ARHGAP36. Nat Commun. 2016;7:12963.

69. Gu T, Zhang Z, Wang J, Guo J, Shen WH, Yin Y. CREB is a novel nuclear target of PTEN phosphatase. Cancer Res. 2011;71:2821-5.

70. Cheng RB, Ma RJ, Wang ZK, Yang SJ, Lin XZ, Rong H, et al. PTEN status is related to cell proliferation and self-renewal independent of CD133 phenotype in the glioma-initiating cells. Mol Cell Biochem. 2011:349:149-57
71. Duan S, Yuan G, Liu X, Ren R, Li J, Zhang W, et al. PTEN deficiency reprogrammes human neural stem cells towards a glioblastoma stem cell-like phenotype. Nat Commun. 2015;6:10068.

72. Tan X, Wang S, Zhu L, Wu C, Yin B, Zhao J, et al. CAMP response element-binding protein promotes gliomagenesis by modulating the expression of oncogenic microRNA-23a. Proc Natl Acad Sci USA. 2012;109:15805-10.

73. Gampe K, Brill MS, Momma S, Götz M, Zimmermann H. EGF induces CREB and ERK activation at the wall of the mouse lateral ventricles. Brain Res. 2011;1376:31-41.

74. Feng H, Hu B, Vuori K, Sarkaria JN, Furnari FB, Cavenee WK, et al. EGFRvIII stimulates glioma growth and invasion through PKA-dependent serine phosphorylation of Dock180. Oncogene. 2014;33:2504-12.

75. Feng H, Li Y, Yin Y, Zhang W, Hou Y, Zhang L, et al. Protein kinase A-dependent phosphorylation of Dock180 at serine residue 1250 is important for glioma growth and invasion stimulated by platelet derived-growth factor receptor a. Neuro Oncol. 2015;17:832-42.

76. Wang H, Sun T, Hu J, Zhang R, Rao Y, Wang S, et al. miR-33a promotes glioma-initiating cell self-renewal via PKA and NOTCH pathways. J Clin Invest. 2014;124:4489-502.

77. Lo HW, Antoun GR, Ali-Osman F. The human glutathione S-transferase P1 protein is phosphorylated and its metabolic function enhanced by the Ser/Thr protein kinases, CAMP-dependent protein kinase and protein kinase C, in glioblastoma cells. Cancer Res. 2004;64:9131-8.

78. Seo HS, Liu DD, Bekele BN, Kim MK, Pisters K, Lippman SM, et al. Cyclic AMP response element-binding protein overexpression: a feature associated with negative prognosis in never smokers with non-small cell lung cancer. Cancer Res. 2008;68:6065-73.

79. Kim EJ, Juhnn YS. Cyclic AMP signaling reduces sirtuin 6 expression in non-small cell lung cancer cells by promoting ubiquitin-proteasomal degradation via inhibition of the Raf-MEK-ERK (Raf/mitogen-activated extracellular signal-regulated kinase/extracellular signal-regulated kinase) pathway. J Biol Chem. 2015;290:9604-13.

80. Xia Y, Zhan C, Feng M, Leblanc M, Ke E, Yeddula N, et al. Targeting CREB pathway suppresses small cell lung cancer. Mol Cancer Res. 2018;16:825-32.

81. James MA, Lu Y, Liu Y, Vikis HG, You M. RGS17, an overexpressed gene in human lung and prostate cancer, induces tumor cell proliferation through the cyclic AMP-PKA-CREB pathway. Cancer Res. 2009;69:2108-16.

82. Li H, Xiao N, Wang Y, Wang R, Chen Y, Pan W, et al. Smurf1 regulates lung cancer cell growth and migration through interaction with and ubiquitination of PIPKIy. Oncogene. 2017;36:5668-80.

83. Pullamsetti SS, Banat GA, Schmall A, Szibor M, Pomagruk D, Hänze J, et al. Phosphodiesterase-4 promotes proliferation and angiogenesis of lung cancer by crosstalk with HIF. Oncogene. 2013;32:1121-34.

84. Shaikh D, Zhou Q, Chen T, Ibe JCF, Raj JU, Zhou G. CAMP-dependent protein kinase is essential for hypoxia-mediated epithelial-mesenchymal transition, migration, and invasion in lung cancer cells. Cell Signal. 2012;24:2396-406.

85. Barlow CA, Kitiphongspattana K, Siddiqui N, Roe MW, Mossman BT, Lounsbury KM. Protein kinase A-mediated CREB phosphorylation is an oxidant-induced survival pathway in alveolar type II cells. Apoptosis. 2008;13:681-92.

86. Cho EA, Kim EJ, Kwak SJ, Juhnn YS. CAMP signaling inhibits radiationinduced ATM phosphorylation leading to the augmentation of apoptosis in human lung cancer cells. Mol Cancer. 2014;13:36.

87. Choi YJ, Kim SY, Oh JM, Juhnn YS. Stimulatory heterotrimeric G protein augments gamma ray-induced apoptosis by up-regulation of Bak expression via CREB and AP-1 in H1299 human lung cancer cells. Exp Mol Med. 2009;41:592-600.

88. Pollack A, Bae K, Khor LY, Al-Saleem T, Hammond ME, Venkatesan V, et al. The importance of protein kinase $A$ in prostate cancer: relationship to patient outcome in Radiation Therapy Oncology Group trial 92-02. Clin Cancer Res. 2009;15:5478-84.

89. Neary CL, Nesterova M, Cho YS, Cheadle C, Becker KG, Cho-Chung YS. Protein kinase A isozyme switching: eliciting differential CAMP signaling and tumor reversion. Oncogene. 2004;23:8847-56.

90. Singh JP, Dagar M, Dagar G, Kumar S, Rawal S, Sharma RD, et al. Activation of GPR56, a novel adhesion GPCR, is necessary for nuclear androgen receptor signaling in prostate cells. PLoS ONE. 2020;15:e0226056. 
91. Dagar M, Singh JP, Dagar G, Tyagi RK, Bagchi G. Phosphorylation of HSP90 by protein kinase $A$ is essential for the nuclear translocation of androgen receptor. J Biol Chem. 2019;294:8699-710.

92. Deeble PD, Murphy DJ, Parsons SJ, Cox ME. Interleukin-6- and cyclic AMP-mediated signaling potentiates neuroendocrine differentiation of LNCaP prostate tumor cells. Mol Cell Biol. 2001;21:8471-82.

93. Cox ME, Deeble PD, Bissonette EA, Parsons SJ. Activated 3',5'-cyclic AMP-dependent protein kinase is sufficient to induce neuroendocrinelike differentiation of the LNCaP prostate tumor cell line. J Biol Chem. 2000;275:13812-8.

94. Huang WC, Xie Z, Konaka H, Sodek J, Zhau HE, Chung LW. Human osteocalcin and bone sialoprotein mediating osteomimicry of prostate cancer cells: role of CAMP-dependent protein kinase A signaling pathway. Cancer Res. 2005;65:2303-13.

95. Park MH, Lee HS, Lee CS, You ST, Kim DJ, Park BH, et al. p21-Activated kinase 4 promotes prostate cancer progression through CREB. Oncogene. 2013;32:2475-82.

96. Hassan S, Karpova Y, Baiz D, Yancey D, Pullikuth A, Flores A, et al. Behavioral stress accelerates prostate cancer development in mice. J Clin Invest. 2013:123:874-86.

97. Linnerth NM, Greenaway JB, Petrik JJ, Moorehead RA. cAMP response element-binding protein is expressed at high levels in human ovarian adenocarcinoma and regulates ovarian tumor cell proliferation. Int J Gynecol Cancer. 2008;18:1248-57.

98. Mcdaid HM, Cairns MT, Atkinson RJ, Mcaleer S, Harkin DP, Gilmore P, et al. Increased expression of the Rlalpha subunit of the CAMP-dependent protein kinase $\mathrm{A}$ is associated with advanced stage ovarian cancer. Br J Cancer. 1999;79:933-9.

99. Mckenzie AJ, Campbell SL, Howe AK. Protein kinase A activity and anchoring are required for ovarian cancer cell migration and invasion. PLOS ONE. 2011;6:e26552.

100. D'souza T, Agarwal R, Morin PJ. Phosphorylation of claudin-3 at threonine 192 by CAMP-dependent protein kinase regulates tight junction barrier function in ovarian cancer cells. J Biol Chem. 2005;280:26233-40.

101. Choi JH, Choi KC, Auersperg N, Leung PCK. Gonadotropins activate proteolysis and increase invasion through protein kinase $\mathrm{A}$ and phosphatidylinositol 3-kinase pathways in human epithelial ovarian cancer cells. Cancer Res. 2006:66:3912-20.

102. Özeş AR, Pulliam N, Ertosun MG, Yılmaz Ö, Tang J, Çopuroğlu E, et al. Protein kinase A-mediated phosphorylation regulates STAT3 activation and oncogenic EZH2 activity. Oncogene. 2018;37:3589-600.

103. Paul MR, Pan TC, Pant DK, Shih NN, Chen Y, Harvey KL, et al. Genomic landscape of metastatic breast cancer identifies preferentially dysregulated pathways and targets. J Clin Invest. 2020;130:4252-65.

104. Wang $Z$, Li Y, Xiao Y, Lin H-P, Yang $P$, Humphries $B$, et al. Integrin a9 depletion promotes $\beta$-catenin degradation to suppress triplenegative breast cancer tumor growth and metastasis. Int J Cancer 2019;145:2767-80.

105. Miller WR. Regulatory subunits of PKA and breast cancer. Ann NY Acad Sci. 2002;968:37-48.

106. Kok M, Zwart W, Holm C, Fles R, Hauptmann M, Van't Veer LJ, et al. PKAinduced phosphorylation of ERa at serine 305 and high PAK1 levels is associated with sensitivity to tamoxifen in ER-positive breast cancer. Breast Cancer Res Treat. 2011;125:1-12.

107. Hua $\mathrm{H}$, Zhang $\mathrm{H}$, Kong Q, Jiang Y. Mechanisms for estrogen receptor expression in human cancer. Exp Hematol Oncol. 2018;7:24.

108. Moody SE, Schinzel AC, Singh S, Izzo F, Strickland MR, Luo L, et al. PRKACA mediates resistance to HER2-targeted therapy in breast cancer cells and restores anti-apoptotic signaling. Oncogene. 2015;34:2061-71.

109. Sola-Penna M, Paixão LP, Branco JR, Ochioni AC, Albanese JM, Mundim DM, et al. Serotonin activates glycolysis and mitochondria biogenesis in human breast cancer cells through activation of the Jak1/STAT3/ERK1/2 and adenylate cyclase/PKA, respectively. Br J Cancer. 2020;122:194-208.

110. Yu T, Yang G, Hou Y, Tang X, Wu C, Wu XA, et al. Cytoplasmic GPER translocation in cancer-associated fibroblasts mediates CAMP/PKA/ CREB/glycolytic axis to confer tumor cells with multidrug resistance. Oncogene. 2017;36:2131-45.

111. Persaud L, Mighty J, Zhong X, Francis A, Mendez M, Muharam H, et al. IL-24 promotes apoptosis through cAMP-dependent PKA pathways in human breast cancer cells. Int J Mol Sci. 2018;19:3561.
112. Kim DH, Lerner A. Type 4 cyclic adenosine monophosphate phosphodiesterase as a therapeutic target in chronic lymphocytic leukemia. Blood. 1998:72:2484-94.

113. Tan Y, Watkins AA, Freeman BB, Meyers JA, Rifkin IR, Lerner A. Inhibition of type 4 cyclic nucleotide phosphodiesterase blocks intracellular TLR signaling in chronic lymphocytic leukemia and normal hematopoietic cells. J Immunol. 2015;194:101-12.

114. Meyers JA, Taverna J, Chaves J, Makkinje A, Lerner A. Phosphodiesterase 4 inhibitors augment levels of glucocorticoid receptor in B cell chronic lymphocytic leukemia but not in normal circulating hematopoietic cells. Clin Cancer Res. 2007;13:4920-7.

115. Meyers JA, Su DW, Lerner A. Chronic lymphocytic leukemia and B and $T$ cells differ in their response to cyclic nucleotide phosphodiesterase inhibitors. J Immunol. 2009;182:5400-11.

116. Zambon AC, Zhang L, Minovitsky S, Kanter JR, Prabhakar S, Salomonis $\mathrm{N}$, et al. Gene expression patterns define key transcriptional events in cell-cycle regulation by cAMP and protein kinase A. Proc Natl Acad Sci USA. 2005;102:8561-6.

117. Zhang L, Zambon AC, Vranizan K, Pothula K, Conklin BR, Insel PA. Gene expression signatures of CAMP/protein kinase A (PKA)-promoted, mitochondrial-dependent apoptosis. Comparative analysis of wild-type and cAMP-deathless S49 lymphoma cells. J Biol Chem. 2008;283:4304-13.

118. Mamani-Matsuda M, Moynet D, Molimard M, Ferry-Dumazet H, Marit G, Reiffers J, et al. Long-acting beta2-adrenergic formoterol and salmeterol induce the apoptosis of B-chronic lymphocytic leukaemia cells. Br J Haematol. 2004;124:141-50.

119. Burger JA, Burger M, Kipps TJ. Chronic lymphocytic leukemia B cells express functional CXCR4 chemokine receptors that mediate spontaneous migration beneath bone marrow stromal cells. Blood. 1999;94:3658-67.

120. Burger JA, Tsukada N, Burger M, Zvaifler NJ, Dell'aquila M, Kipps TJ. Blood-derived nurse-like cells protect chronic lymphocytic leukemia B cells from spontaneous apoptosis through stromal cell-derived factor-1. Blood. 2000;96:2655-63.

121. Zhang L, Murray F, Zahno A, Kanter JR, Chou D, Suda R, et al. Cyclic nucleotide phosphodiesterase profiling reveals increased expression of phosphodiesterase 7B in chronic lymphocytic leukemia. Proc Natl Acad Sci USA. 2008:105:19532-7.

122. Crans-Vargas HN, Landaw EM, Bhatia S, Sandusky G, Moore TB, Sakamoto KM. Expression of cyclic adenosine monophosphate responseelement binding protein in acute leukemia. Blood. 2002;99:2617-9.

123. Illiano M, Conte M, Salzillo A, Ragone A, Spina A, Nebbioso A, et al. The KDM inhibitor GSKJ4 triggers CREB downregulation via a protein kinase $\mathrm{A}$ and proteasome-dependent mechanism in human acute myeloid leukemia cells. Front Oncol. 2020;10:799.

124. Safa M, Mousavizadeh K, Noori S, Pourfathollah A, Zand H. CAMP protects acute promyelocytic leukemia cells from arsenic trioxide-induced caspase-3 activation and apoptosis. Eur J Pharmacol. 2014;736:115-23.

125. Huseby S, Gausdal G, Keen TJ, Kjaerland E, Krakstad C, Myhren L, et al. Cyclic AMP induces IPC leukemia cell apoptosis via CRE-and CDKdependent Bim transcription. Cell Death Dis. 2011;2:e237.

126. Wang M, Li Y, Wang R, Wang Z, Chen K, Zhou B, et al. PKA Rla/A-kinase anchoring proteins 10 signaling pathway and the prognosis of colorectal cancer. J Gastroenterol Hepatol. 2015;30:496-503.

127. Hua $\mathrm{H}$, Kong $\mathrm{Q}$, Yin J, Zhang J, Jiang Y. Insulin-like growth factor receptor signaling in tumorigenesis and drug resistance: a challenge for cancer therapy. J Hematol Oncol. 2020;13:64.

128. Leiphrakpam PD, Brattain MG, Black JD, Wang J. TGF $\beta$ and IGF1R signaling activates protein kinase $A$ through differential regulation of ezrin phosphorylation in colon cancer cells. J Biol Chem. 2018;293:8242-54.

129. Troiani T, Vecchione L, Martinelli E, Capasso A, Costantino S, Ciuffreda LP et al. Intrinsic resistance to selumetinib, a selective inhibitor of MEK1/2, by CAMP-dependent protein kinase $\mathrm{A}$ activation in human lung and colorectal cancer cells. Br J Cancer. 2012:106:1648-59.

130. Xian D, Zhao Y. LncRNA KCNQ1OT1 enhanced the methotrexate resistance of colorectal cancer cells by regulating miR-760/PPP1R1B via the CAMP signalling pathway. J Cell Mol Med. 2019;23:3808-23.

131. Brudvik KW, Paulsen JE, Aandahl EM, Roald B, Taskén K. Protein kinase A antagonist inhibits b-catenin nuclear translocation, c-Myc and COX-2 expression and tumor promotion in ApcMin/+ mice. Mol Cancer. 2011:10:149. 
132. Mantovani G, Bondioni S, Lania AG, Rodolfo M, Peverelli E, Polentarutti $\mathrm{N}$, et al. High expression of PKA regulatory subunit 1A protein is related to proliferation of human melanoma cells. Oncogene. 2008;27:1834-43.

133. Finger EC, Castellini L, Rankin EB, Vilalta M, Krieg AJ, Jiang D, et al. Hypoxic induction of AKAP12 variant 2 shifts PKA-mediated protein phosphorylation to enhance migration and metastasis of melanoma cells. Proc Natl Acad Sci USA. 2015;112:4441-6.

134. Jian D, Jiang D, Su J, Chen W, Hu X, Kuang Y, et al. Diethylstilbestrol enhances melanogenesis via CAMP-PKA-mediating up-regulation of tyrosinase and MITF in mouse B16 melanoma cells. Steroids. 2011;76:1297-304.

135. Huang HC, Chou YC, Wu CY, Chang TM. [8]-Gingerol inhibits melanogenesis in murine melanoma cells through down-regulation of the MAPK and PKA signal pathways. Biochem Biophys Res Commun. 2013;438:375-81.

136. Cho-Chung YS, Nesterova MV. Tumor reversion: protein kinase A isozyme switching. Ann NY Acad Sci. 2005;1058:76-86.

137. Schwede F, Maronde E, Genieser H, Jastorff B. Cyclic nucleotide analogs as biochemical tools and prospective drugs. Pharmacol Ther. 2000:87:199-226.

138. Choi KY, Ahn YH, Ahn HW, Cho YJ, Hong SH. Involvement of Akt2/ protein kinase $B \beta(P K B \beta)$ in the 8-Cl-cAMP-induced cancer cell growth inhibition. J Cell Physiol. 2013;228:890-902.

139. Robinson-White AJ, Hsiao HP, Leitner WW, Greene E, Bauer A, Krett $\mathrm{NL}$, et al. Protein kinase A-independent inhibition of proliferation and induction of apoptosis in human thyroid cancer cells by 8-Cl-adenosine. J Clin Endocrinol Metab. 2008:93:1020-9.

140. Matera MG, Page C, Cazzola M. PDE inhibitors currently in early clinical trials for the treatment of asthma. Expert Opin Investig Drugs. 2014;23:1267-75

141. Yu B, Ragazzon B, Rizk-Rabin M, Bertherat J. Protein kinase A alterations in endocrine tumors. Horm Metab Res. 2012;44:741-8.

142. Omar F, Findlay JE, Carfray G, Allcock RW, Jiang Z, Moore C, et al. Smallmolecule allosteric activators of PDE4 long form cyclic AMP phosphodiesterases. Proc Natl Acad Sci USA. 2019;116:13320-9.

143. Cho-Chung YS. Antisense protein kinase A RI alpha-induced tumor reversion: portrait of a microarray. Biochim Biophys Acta. 2004;1697:71-9.
144. Goel S, Desai K, Macapinlac M, Wadler S, Goldberg G, Fields A, et al. A phase I safety and dose escalation trial of docetaxel combined with GEM231, a second generation antisense oligonucleotide targeting protein kinase A R1alpha in patients with advanced solid cancers. Invest New Drugs. 2006;24:125-34

145. Mitton B, Chae HD, Hsu K, et al. Small molecule inhibition of CAMP response element binding protein in human acute myeloid leukemia cells. Leukemia. 2016;30:2302-11.

146. Chae HD, Cox N, Dahl GV, Lacayo NJ, Davis KL, Capolicchio S, et al. Niclosamide suppresses acute myeloid leukemia cell proliferation through inhibition of CREB-dependent signaling pathways. Oncotarget. 2017;9:4301-17.

147. Kang X, Cui C, Wang C, Wu G, Chen H, Lu Z, et al. CAMKs support development of acute myeloid leukemia. J Hematol Oncol. 2018;11:30.

148. Insel PA, Zhang L, Murray F, Yokouchi H, Zambon AC. Cyclic AMP is both a pro-apoptotic and anti-apoptotic second messenger. Acta Physiol (Oxf). 2012;204:277-87.

149. Wilderman A, Guo Y, Divakaruni AS, Perkins G, Zhang L, Murphy AN, et al. Proteomic and metabolic analyses of S49 lymphoma cells reveal novel regulation of mitochondria by CAMP and protein kinase A. J Biol Chem. 2015;290:22274-86.

150. Zambon AC, Wilderman A, Ho A, Insel PA. Increased expression of the pro-apoptotic protein BIM, a mechanism for CAMP/protein kinase A (PKA)-induced apoptosis of immature T cells. J Biol Chem. 2011;286:33260-7.

151. Jewell JL, Fu V, Hong AW, Yu FX, Meng D, Melick CH, et al. GPCR signaling inhibits mTORC1 via PKA phosphorylation of Raptor. Elife. 2019;8:e43038.

\section{Publisher's Note}

Springer Nature remains neutral with regard to jurisdictional claims in published maps and institutional affiliations.
Ready to submit your research? Choose BMC and benefit from:

- fast, convenient online submission

- thorough peer review by experienced researchers in your field

- rapid publication on acceptance

- support for research data, including large and complex data types

- gold Open Access which fosters wider collaboration and increased citations

- maximum visibility for your research: over $100 \mathrm{M}$ website views per year

At BMC, research is always in progress.

Learn more biomedcentral.com/submissions 